\title{
EFEKTIVITAS EKSTRAK DAUN BUNGA PUKUL EMPAT UNTUK PENGENDALIAN PENYAKIT MOSAIK KACANG PANJANG
}

\author{
Supyani ${ }^{1}$ ), Sri Widadi ${ }^{1}$ ), Wahyu Hidayah Andriyani Jamil ${ }^{2}$ ) \\ $\left.{ }_{1}^{1}\right)$ Staf Dosen Program Studi Agroteknologi, Fakultas Pertanian, Universitas Sebelas Maret \\ 2) Mahasiswa S1 Program Studi Agroteknologi, Fakultas Pertanian, Universitas Sebelas Maret \\ Contact Author: hidayahw55@yahoo.com
}

\begin{abstract}
Production of long beans has declined, caused by mosaic virus infection. The disease was still difficult to be control. This study aims to determine role and to measure the effectivity of Mirabilis jalapa leaf extract to inhibit long bean mosaic disease, based on the concentration of extract and time of application. The Research was arranged by Completely Randomized Design (CRD) with two factors, time of application, and concentration of $M$. jalapa leaf extract. Data were analyzed using $F$ test and DMRT (Duncans Multiple Range Test) at level of $5 \%$. The results showed that application of $M$. jalapa leaf extract $25 \%$ one day before inoculation was best treatment to delay the emergence of the mosaic disease symptoms up to 32 days and able to increase the average weight of pods up to 104,45 grams. Soaking the seeds to extract $25 \%$ were able to suppress the virus up to $96,93 \%$. The Application of M. jalapa leaf extract $50 \%$ with symptomatic leaf sap of mosaic simultaneously showed highest in plant's fresh weight and biomass weight. Concentration of $M$. jalapa leaf extract $25 \%$, which applied one day before inoculation was most effective to control the mosaic virus disease.
\end{abstract}

Keyword: long beans, M. jalapa leaf extract, long bean mosaic diseases.

\section{AGROTECHNOLOGY RESEARCH JOURNAL}

Supyani, Widadi S, Jamil WHA. 2017. Effectivity of Mirabilis jalapa leaf extract to control long bean mosaic diseases. Agrotech Res J 1(1): 33-40.

Supyani, Widadi S, Jamil WHA. 2017. Efektivitas ekstrak daun bunga pukul empat untuk pengendalian penyakit mosaik kacang panjang. Agrotech Res J 1(1): 33-40.

\section{PENDAHULUAN}

Kacang panjang merupakan salah satu sayuran yang banyak dikonsumsi oleh masayarakat di Indonesia, tetapi dalam kurun waktu lima tahun terakhir produksi kacang panjang di Indonesia cenderung menurun. Berdasarkan data, produksi kacang panjang nasional tahun 2011 sampai 2015 yaitu 458.307 ton, 455.615 ton, 450.859 ton, 450.709 ton dan 399.078 ton (Kementrian Pertanian 2016). Penurunan produksi kacang panjang salah satunya disebabkan virus penyebab penyakit mosaik. Penyakit mosaik dapat disebabkan oleh infeksi virus tunggal atau campuran, diantaranya MYMIV (Nurulita et al. 2015), BCMV-BIC dan CMV (Damayanti et al. 2009).

Penyakit mosaik kacang panjang yang disebabkan infeksi BCMV mengalami penurunan produksi polong 27,1-85,2 \% (Susetio dan Hidayat 2014) dan memperlambat kemasakan polong (Damayanti dan Hamdayanti 2014). Tahun 2009, penyebaran penyakit mosaik kacang panjang meluas di beberapa daerah Jawa Barat dan Jawa Tengah, seperti Bogor, Karawang, Subang, Indramayu, Cirebon, Tegal dan Pekalongan (Damayanti 2010). Penyakit mosaik kacang panjang masih sulit dikendalikan karena dapat ditularkan oleh vektor yaitu kutu daun (Aphis craccivora) (Susetio 2011) dan bersifat tular benih. Benih kacang panjang komerisal seperti varietas Parade, New Jaliteng, Long Silk, Pilar, 777, Maharani dan Lousiana belum bebas dari BCMV (Mahar 2012).
Pengendalian virus yang dilakukan petani pada umumnya hanya mampu mengendalikan vektornya yaitu dengan pestisida, sehingga upaya ini kurang efektif untuk mengendalikan virus serta kurang sehat untuk lingkungan. Salah satu cara untuk mengatasi permasalahan tersebut adalah dengan menggunakan antiviral atau virus inhibitor yang berasal dari tanaman agar lebih efektif pengendaliannya serta ramah lingkungan. Antiviral ini dapat diperoleh dengan mengekstrak tanaman tertentu yang memiliki zat penghambat virus. Salah satu tanaman yang diketahui memiliki peran sebagai antiviral adalah daun bunga pukul empat (Mirabilis jalapa).

Ekstrak daun bunga pukul empat ( $M$. jalapa) diketahui mempunyai kemampuan dalam menginduksi ketahanan tanaman. Ekstrak bunga pukul empat mengandung protein antivirus yang dapat digunakan sebagai alternatif pengendalian virus. Hasil yang diperoleh dari penelitiannya tersebut menyatakan bahwa ekstrak bunga pukul empat mampu menghambat penyebaran dan perkembangan potato virus $X$ (PVX) hingga 99\%, potato virus $Y$ (PVY), dan potato spindle tuber viroid (PSTVd) sebesar $100 \%$. (Vivanco et al. 1999). Ekstrak daun bunga pukul empat perlu diujikan pada virus penyebab mosaik kacang panjang sehingga dapat diketahui efektivitasnya.

${ }^{*}$ Fak. Pertanian UNS Surakarta

JI. Ir. Sutami 36 A Surakarta 


\section{BAHAN DAN METODE}

Penelitian dilaksanakan mulai bulan November 2015 sampai bulan Juli 2016. Perbanyakan inokulum dilakukan di rumah kasa dan Laboratorium Hama Penyakit Tumbuhan (HPT), Fakultas Pertanian, Universitas Sebelas Maret (UNS) Surakarta sedangkan penanaman tanaman percobaan dilakukan di rumah kaca milik Laboratorium Pengamatan Hama dan Penyakit (LPHP) Sukoharjo. Bahan yang digunakan dalam penelitian ini adalah isolat virus penyebab mosaik kacang panjang yang diperoleh dari lahan pertanian di Desa Joho, Kecamatan Mojolaban, Kabupaten Sukoharjo, tanaman Indikator Chenopodium amaranticolor, benih kacang panjang varietas Parade, ekstrak daun bunga pukul empat, buffer fosfat $\mathrm{pH} 7$, carborundum 600 mesh, Alkohol 70\%, akuadest, tanah steril sarung tangan, dan cutton buds. Peralatan yang digunakan meliputi mortar, pistil, sprayer, polybag $30 \times 30 \mathrm{~cm}$, timbangan, cethok, ember dan gembor.

Percobaan menggunakan Rancangan Acak Lengkap (RAL) dengan 2 faktor. Faktor pertama yaitu waktu aplikasi yang terdiri dari 5 taraf yaitu $\mathrm{W} 1=$ Perendaman, $\mathrm{W} 2=$ aplikasi satu hari sebelum inokulasi sap daun bergejala mosaik, W3 $=$ inokulasi ekstrak bersama sap daun bergejala mosaik, W4= aplikasi satu hari setelah inokulasi sap daun bergejala mosaik dan W5 = kontrol tanaman sehat, sedangkan faktor kedua yaitu konsentrasi ekstrak daun bunga pukul empat, terdiri dari 4 taraf $=\mathrm{E} 1=$ ekstrak daun $M$. jalapa $0 \%($ kontrol dengan buffer fosfat), E2= ekstrak daun $M$. jalapa 12,5\%, E3= ekstrak daun M. jalapa $25 \%$ dan $\mathrm{E} 4=$ ekstrak daun $M$. jalapa 50\%. Kedua faktor dikombinasikan sehingga diperoleh 20 perlakuan. Masing-masing kombinasi perlakuan diulang sebanyak 3 kali sehingga diperoleh 60 unit percobaan.

Pelaksanaan penelitian meliputi perbanyakan inokulum, persiapan media tanam, persiapan ekstrak daun $M$. jalapa, penanaman, aplikasi ekstrak daun $M$. jalapa, inokulasi sap daun kacang panjang bergejala mosaik secara mekanis, pemeliharaan tanaman dan panen. Peubah yang diamati yaitu masa inkubasi, intensitas penyakit mosaik, waktu muncul bunga, bobot polong segar, bobot brangkasan segar dan bobot brangkasan kering kacang panjang. Data yang diperoleh dianalisis menggunakan uji $F 5 \%$, kemudian apabila berpengaruh nyata dilanjutkan dengan uji DMRT (Duncan Multiple Range Test) pada taraf nyata $5 \%$.

\section{HASIL DAN PEMBAHASAN}

\section{Masa inkubasi}

Masa inkubasi merupakan tenggang waktu antara masuknya virus hingga timbulnya gejala pertama pada tanaman (Boss 1990). Kebanyakan virus memerlukan waktu 2-5 hari untuk pindah dari daun yang diinokulasi (Agrios 2005). Masa inkubasi virus penyebab mosaik yang diinokulasikan pada kacang panjang menunjukkan

hasil yang bervariasi. Kacang panjang yang diaplikasikan ekstrak daun $M$. jalapa menunjukkan masa inkubasi yang lebih panjang dibandingkan dengan kacang panjang yang tidak diaplikasikan ekstrak daun M. jalapa (Gambar 1).

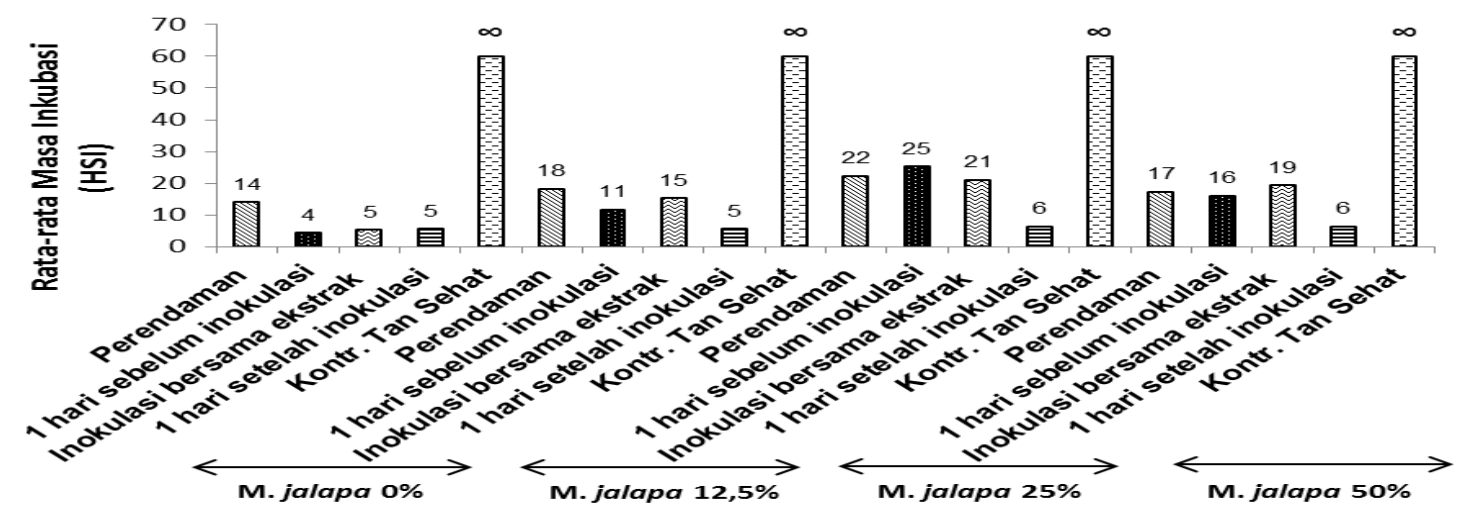

Kombinasi Perlakuan Waktu Aplikasi dan Konsentrasi

Keterangan : $\mathrm{HSI}=$ Hari Setelah Inokulasi, $\infty=$ Masa inkubasi tak terhingga, Kontr. Tan. Sehat $=$ Kontrol tanaman sehat

Gambar 1 Pengaruh waktu aplikasi dan konsentrasi ekstrak daun M. Jalapa terhadap masa inkubasi penyakit mosaik kacang panjang

Kombinasi perlakuan antara konsentrasi ekstrak daun $M$. jalapa dan waktu aplikasi, secara umum menunjukkan masa inkubasi yang lebih panjang dibandingkan dengan kacang panjang yang tidak diaplikasikan ekstrak daun $M$. jalapa (Kontrol). Perlakuan ekstrak daun M. jalapa konsentrasi $25 \%$ satu hari sebelum aplikasi inokulum virus, merupakan kombinasi perlakuan terbaik karena memiliki masa inkubasi paling lama, yakni 32 hari. Hal ini sesuai dengan Duriat (2008), bahwa tanaman cabai yang sudah diinduksi dengan ekstrak nabati kemudian diinfeksi (challenged) dengan virus Gemini dapat memperpanjang masa inkubasi. Pada waktu 24 jam setelah induksi (JSI) tanaman cabai memiliki daya 
hambat yang paling tinggi, sehingga masa inkubasinya menjadi lebih lama. Dibandingkan dengan perlakuan kontrol, ekstrak bunga pukul empat dapat menekan

\section{Intensitas penyakit}

Intensitas penyakit adalah angka dari area atau volume jaringan sakit dibandingkan dengan seluruh area atau volume jaringan (Ginting 2013). Proses fisiologi yang terganggu setelah virus masuk ke dalam tanaman, maka hal pertama yang dilakukan virus adalah mereplikasi diri serta pembentukan protein, masa inkubasi 2 kali lebih lama (105,8\%), sedangkan perlakuan lain dapat memperpanjang masa inkubasi sedikitnya $23 \%$.

untuk menguasai tubuh tanaman, saat proses ini terjadi, tanaman akan mengalami peningkatan aktivitas protein anaplerotik, peningkatan laju fotosintesis dan peningkatan kandungan pati. Setelah laju replikasi menurun maka laju fotosintesis pun akan menurun (Te'csi et al. 1996).

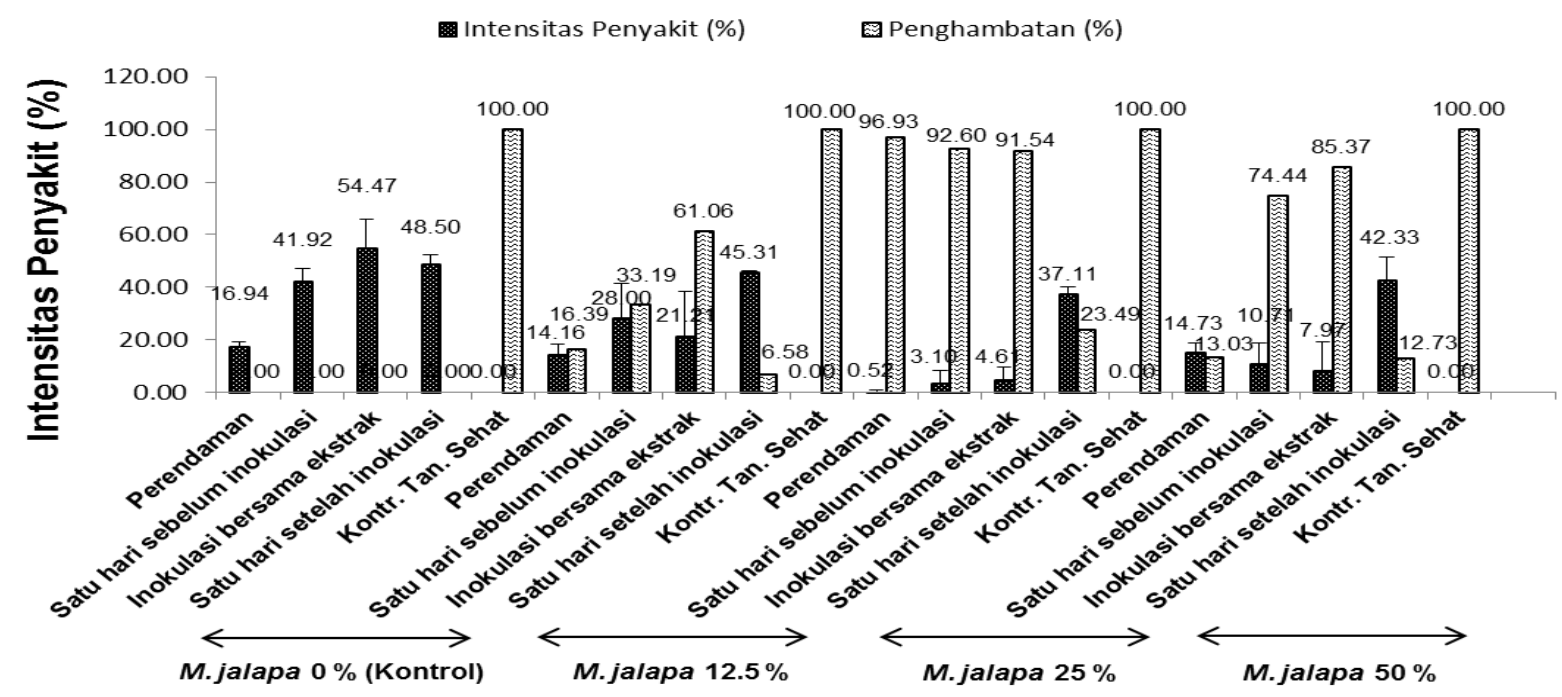

\section{Kombinasi Perlakuan Waktu Aplikasi dan Konsentrasi Ekstrak}

Keterangan : Kontr. Tan Sehat = Kontrol tanaman sehat,

Gambar 2 Pengaruh waktu aplikasi dan konsentrasi ekstrak daun M. Jalapa terhadap intensitas penyakit mosaik kacang panjang

Kacang panjang yang diaplikasikan ekstrak daun $M$. jalapa pada semua konsentrasi mampu menekan intensitas penyakit, serta menunjukkan hasil yang lebih baik dibanding dengan kontrol tanaman sakit (kacang panjang yang tidak diaplikasikan ekstrak daun $M$. jalapa) Berdasarkan hasil pengamatan, konsentrasi ekstrak terbaik, yang mampu menekan intensitas penyakit, adalah kacang panjang yang direndam dengan ekstrak daun $M$. jalapa $25 \%$ karena mampu menekan intensitas penyakit paling tinggi dibandingkan perlakuan lainnya (Gambar 2).

Aplikasi ekstrak daun M.jalapa perlakuan perendaman benih menunjukkan penekanan intensitas penyakit paling tinggi. Mekanisme penekanan intensitas penyakit oleh ekstrak daun M.jalapa belum diketahui dengan jelas, hal ini dimungkinkan karena terjadinya peningkatan aktivitas enzim peroksidase dan peningkatan kandungan asam salisilat. Hersanti (2004) menyatakan bahwa cabai merah yang diinduksi ketahanannya terhadap serangan CMV oleh ekstrak

\section{Waktu muncul bunga}

Infeksi virus menyebabkan pembentukan bunga terhambat dan menurunkan jumlah bunga yang dihasilkan (Agrios 2005). Aplikasi ekstrak daun M. jalapa dengan berbagai konsentrasi tidak daun $M$. jalapa menunjukkan rendahnya intensitas serangan CMV. Hal ini terjadi karena peningkatan aktivitas enzim peroksidase 2 - $10 \mathrm{kali}$, dan kandungan asam salisilat sebanyak 1,6 - 5 kali dibandingkan dengan tanpa induksi (kontrol). Menurut Madhusudan et al. (2011), benih yang direndam pada minyak meniran meningkatkan vigor benih dan mampu mereduksi konsentrasi virus TMV. Tanaman dengan konsentrasi virus yang rendah memiliki aktivitas peroksidase yang tinggi. Matthews (1981) Cit. Hull (2002), juga menyatakan bahwa aktivitas peroksidase dilaporkan sebagai bentuk respon ketahanan tembakau dari infeksi TMV.

Perendaman biji pada ekstrak daun $M$. jalapa dapat meningkatkan aktivitas enzim peroksidase dan kandungan asam salisilat yang dapat menekan intensitas penyakit mosaik kacang panjang, serta dengan perendaman biji pada ekstrak daun $M$. jalapa dapat meningkatkan vigor benih dan mampu mereduksi konsentrasi virus.

mempengaruhi waktu kemunculan bunga kacang panjang yang terinfeksi virus penyebab mosaik, akan tetapi waktu aplikasi ekstrak berpengaruh terhadap waktu pembungaan (Gambar 3). 


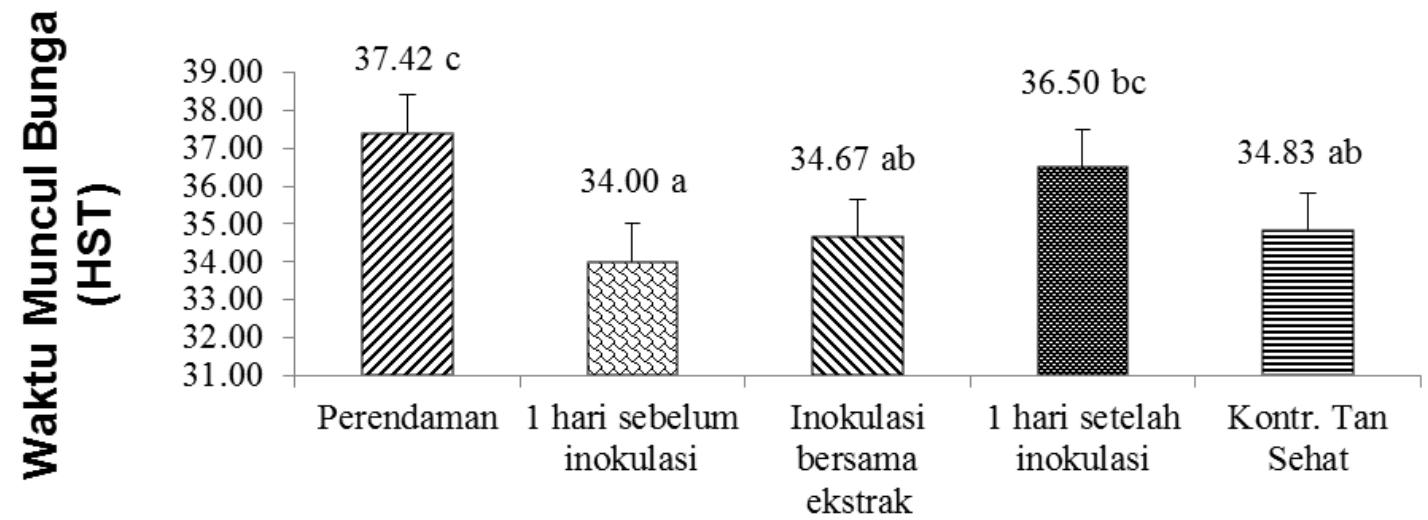

\section{Waktu Aplikasi}

Keterangan : HST = Hari Setelah Tanam, Kontr. Tan Sehat $=$ Kontrol tanaman sehat. Antar angka yang diikuti dengan huruf yang sama tidak berbeda nyata pada taraf $5 \%$

Gambar 3 Pengaruh waktu aplikasi ekstrak daun M. Jalapa terhadap waktu muncul bunga kacang panjang.

Aplikasi ekstrak daun $M$. jalapa pada semua konsentrasi menunjukkan hasil yang tidak berpengaruh nyata terhadap waktu berbunga. Menurut Kurnianingsih (2010) pemberian perlakuan berbagai macam ekstrak tumbuhan tidak mempengaruhi masa berbunga pada kacang panjang yang terinfeksi BCMV. Hal ini menunjukkan bahwa infeksi virus cenderung tidak mempengaruhi waktu pertama muncul bunga, baik yang diberi perlakuan ekstrak maupun yang tidak diberi perlakuan ekstrak, sedangkan waktu aplikasi ekstrak daun $M$. jalapa terhadap waktu muncul bunga menunjukkan hasil yang berpengaruh nyata (Gambar 3).

Hasil menunjukkan bahwa ekstrak daun M.jalapa dengan perlakuan aplikasi 1 hari sebelum aplikasi inokulum dan aplikasi ekstrak secara bersamaan dengan inokulum, menunjukkan waktu berbunga yang tidak berbeda dengan kontrol tanaman sehat. Hal ini terjadi karena penginduksian kacang panjang dengan ekstrak daun $M$. jalapa dapat meningkatkan kandungan asam salisilat, yang memicu aktifnya gengen PR-Protein (Pathogenesis Related Protein) sebagai sinyal tranduksi ketahanan tanaman sehingga waktu muncul bunga kacang panjang tidak berbeda dengan kontrol tanaman sehat. Murphy et al. (2001) menyatakan bahwa asam salisilat merupakan sinyal

\section{Bobot Polong Segar}

Kacang panjang yang terinfeksi virus mosaik akan mengalami penurunan hasil polong segar, bahkan jika sudah sangat parah tanaman tidak mampu menghasilkan polong. Inokulasi BCMV mengurangi transduksi bagi ketahanan tanaman terhadap penyakit. Asam salisilat ini akan mengaktifkan ketahanan tanaman terhadap penyakit. Terinduksinya ketahanan tanaman cabai oleh ekstrak tumbuhan karena semakin meningkatnya kandungan asam salisilat yang dapat memicu terekspresinya gen-gen PR-Protein (Pathogenesis Related Protein), yang berpengaruh pada pencegahan multiplikasi, penyebaran, dan lokalisasi virus pada jaringan yang diinokulasisap daun bergejala virus.

Kacang panjang yang diaplikasikan ektrak daun $M$. jalapa 1 hari setelah inokulasi menunjukkan waktu berbuga yang lebih lama. Hal ini dikarenakan tanaman sudah terinfeksi virus, sehingga mengalami penghambatan pembungaan. Menurut Susetio (2011) kacang panjang yang terinfeksi BCMV cenderung mengalami penghambatan pada fase pembungaan. Kemunculan bunga pertama menjadi lebih lambat dibandingkan tanaman sehat. Menurut Agrios (2005) Pembentukan bunga terhambat karena infeksi virus dapat menurunkan kadar hormon dan merangsang sintesis zat penghambat pertumbuhan serta menyebabkan penurunan jumlah bunga yang dihasilkan. Menurut Susetio dan Hidayat (2014) Tanaman yang terinfeksi BCMV mengalami penundaan waktu berbunga berkisar antara $2-5$ hari.

produksi polong kacang panjang (Hamdayanti dan Damayanti 2014). Pengaruh ekstrak daun $M$. jalapa terhadap rerata bobot polong segar kacang panjang dapat dilihat pada (Gambar 4). 


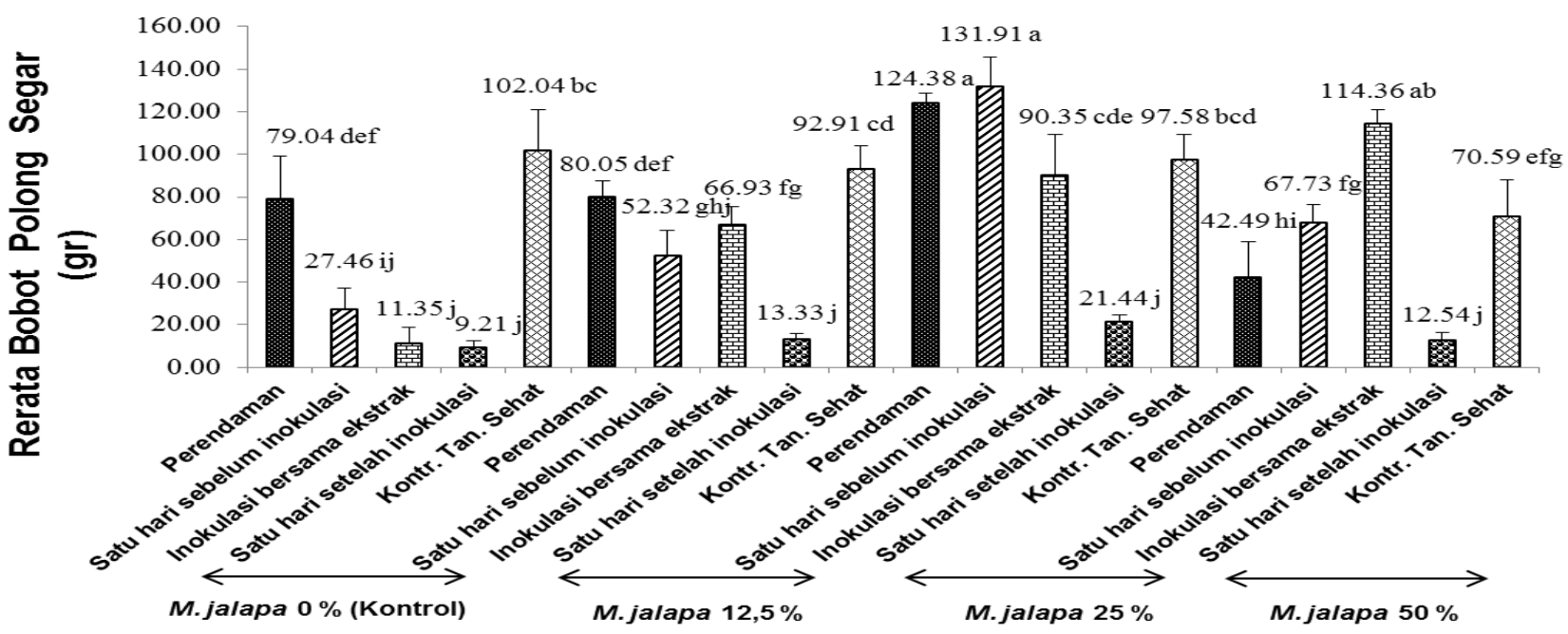

Kombinasi Perlakuan Waktu Aplikasi dan Konsentrasi Ekstrak

Keterangan: Kontr. Tan Sehat $=$ Kontrol tanaman sehat. Antar angka yang diikuti dengan huruf yang sama tidak berbeda nyata pada taraf $5 \%$

Gambar 4 Pengaruh waktu aplikasi dan konsentrasi ekstrak daun M. Jalapa terhadap bobot polong kacang panjang

Kacang panjang yang memiliki bobot polong paling besar, diperoleh dari perlakuan ekstrak daun M. jalapa $25 \%$. yang diaplikasikan satu hari sebelum aplikasi inokulum, hal ini sesuai dengan Hersanti (2004) yang menyatakan bahwa cabai merah yang diinduksi ekstrak M. jalapa konsentrasi 25\% menunjukkan hasil tertinggi yang mencapai dua kali lipat dari hasil cabai merah kontrol. Hasil ini menunjukkan bahwa cabai merah yang diaplikasi ekstrak daun $M$. jalapa mampu mempertahankan hasil cabai merah. Hasil percobaaan didapatkan satu kali aplikasi ekstrak daun bunga pukul empat (M.jalapa) pada konsentrasi $25 \%$ efektif dalam menginduksi ketahanan cabai merah terhadap serangan CMV dengan persentase penghambatan sebesar $89,51 \%$ dibandingkan dengan kontrol dan mampu mempertahankan hasil cabai merah.

Infeksi virus menyebabkan penurunan bobot polong kacang panjang secara nyata. Susetio (2011)

\section{Bobot brangkasan segar}

Infeksi virus TMV meningkatkan konsentrasi hormon asam absisat yang berpengaruh pada penyerapan air, akibatnya pertumbuhan tanaman terhambat dan bobot polong berkurang (Whenham et al. 1986). Aplikasi menyatakan bahwa Infeksi BCMV menyebabkan penurunan bobot polong yang cukup besar. Penurunan bobot polong akibat infeksi BCMV berkisar 27,05\% sampai $85,15 \%$ pada kelima varietas tanaman kacang panjang sehingga berpengaruh terhadap perkembangan dan produksi tanaman.

Tanaman kacang panjang kontrol sakit mengalami penurunan bobot polong segar sebesar $74,4 \%$ dibandingkan kacang panjang control sehat. Penurunan berat polong segar sebesar $27,1-85 \%$ dilaporkan terjadi pada 6 kultivar kacang panjang yang diinokulasi dengan BCMV (Susetio dan Hidayat 2014). Srivastava et al. (2012) juga menyatakan bahwa infeksi BCMV pada hyacinth bean mengindikasikan berkurangnya klorofil a, klorofil b dan total klorofil, sehingga menurunnya produktivitas tanaman terjadi karena meningkatnya respirasi atau menurunnya fotosintesis atau keduanya.

ekstrak daun $M$. jalapa dengan berbagai konsentrasi mempengaruhi bobot brangkasan segar kacang panjang (Gambar 5)

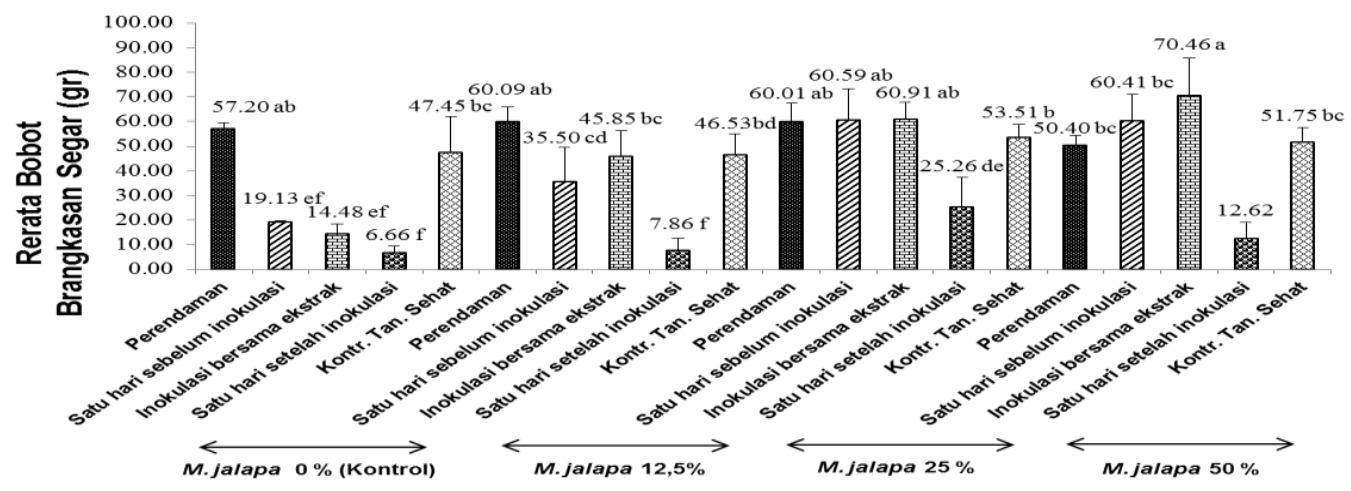

Kombinasi Perlakuan Waktu Aplikasi dan Konsentrasi Ekstrak 
Keterangan : Kontr. Tan Sehat $=$ Kontrol tanaman sehat. Antar angka yang diikuti dengan huruf yang sama tidak berbeda nyata pada taraf $5 \%$

\section{Gambar 5 Pengaruh waktu aplikasi dan konsentrasi ekstrak daun M. Jalapa terhadap bobot brangkasan segar}

Perlakuan Kacang panjang tanpa ekstrak daun $M$. Jalapa menunjukkan hasil terendah dibanding dengan tanaman yang diaplikasi ekstrak. Aplikasi ekstrak daun M. jalapa nyata mampu meningkatkan derajad ketahanan terhadap virus, sehingga mampu mempertahankan zat pengatur tumbuh agar tidak terganggu oleh virus. Agrios (2005) menyatakan Infeksi virus biasanya menyebabkan penurunan zat pengatur tumbuh atau peningkatan zat penghambat tumbuh sehingga berdampak pada metabolisme tanaman.

Kacang panjang yang diberi perlakuan ekstrak daun M. jalapa pada berbagai konsentrasi menunjukkan hasil rerata bobot brangkasan segar lebih tinggi dibanding dengan tanaman yang tidak diberi perlakuan ekstrak $M$. jalapa (kontrol tanaman sakit). Aplikasi ekstrak daun $M$. jalapa pada kombinasi perlakuan antara konsentrasi ekstrak dengan waktu aplikasi menunjukkan hasil yang bervariasi. Aplikasi ekstrak daun M. jalapa $50 \%$ bersamaan dengan inokulasi sap daun bergejala virus merupakan kombinasi perlakuan terbaik, karena menunjukkan bobot brangkasan segar tertinggi. Hal ini terjadi karena kandungan Mirabilis Antiviral Protein

\section{Bobot brangkasan kering}

Brangkasan kering merupakan bahan organik yang terdapat dalam bentuk biomassa, yang mencerminkan penangkapan energi oleh tanaman dalam proses fotosintesis (Hardjadi 1993). Berat brangkasan kering menunjukkan kandungan fotosintat yang dihasilkan oleh tanaman. Besar kecilnya fotosintat yang dihasilkan tergantung pada efektivitas tanaman dalam
(MAP) pada ekstrak daun M. jalapa 50\% mampu berkompetisi dengan virus, sehingga dapat mencegah infeksi virus. Vivanco et al (1999) bahwa mekanisme penghambatan virus yang dilakukan oleh MAP ada dua cara. Yang pertama, pada saat aplikasi ekstrak, MAP masuk ke bagian atas epidermis dan bertahan di ruang antar sel nya. Kedua, MAP dan virus melakukan penetrasi bersama-sama pada saat inokulasi. Keduanya saling berkompetisi untuk mencari daerah aktif ribosom sehingga dapat mencegah infeksi virus pada tahap awal sebelum virus mengalami deenkapsidasi. Menurut Somowiyarjo et al. (2001) cit Hersanti (2004) semakin tinggi tingkat pengenceran ekstrak daun $M$. jalapa semakin kecil daya penghambatan infeksi virusnya. Penghambatan serangan CMV disebabkan juga terdapat senyawa didalam ekstrak daun $M$. jalapa yang berfungsi sebagai bahan antiviral Mafrukhin et al. (2001) cit Hersanti (2004). Tingkat pengenceran yang rendah (konsentrasi ekstrak $M$. jalapa 50\%) maka daya penghambatan MAP pada ekstrak daun $M$. jalapa terhadap virus tinggi.

menjalankan fungsi fisiologinya meliputi fotosintesis dan respirasi. Tanaman yang terinfeksi virus mengalami penurunan laju fotosintesis (Owen 1957, Owen 1958, Leal dan Lastra 1984, Shalitin dan Wolf 2000, El et al 2016) dan peningkatan respirasi (Owen 1957, Owen 1958, Leal dan Lastra 1984, Shalitin dan Wolf 2000).

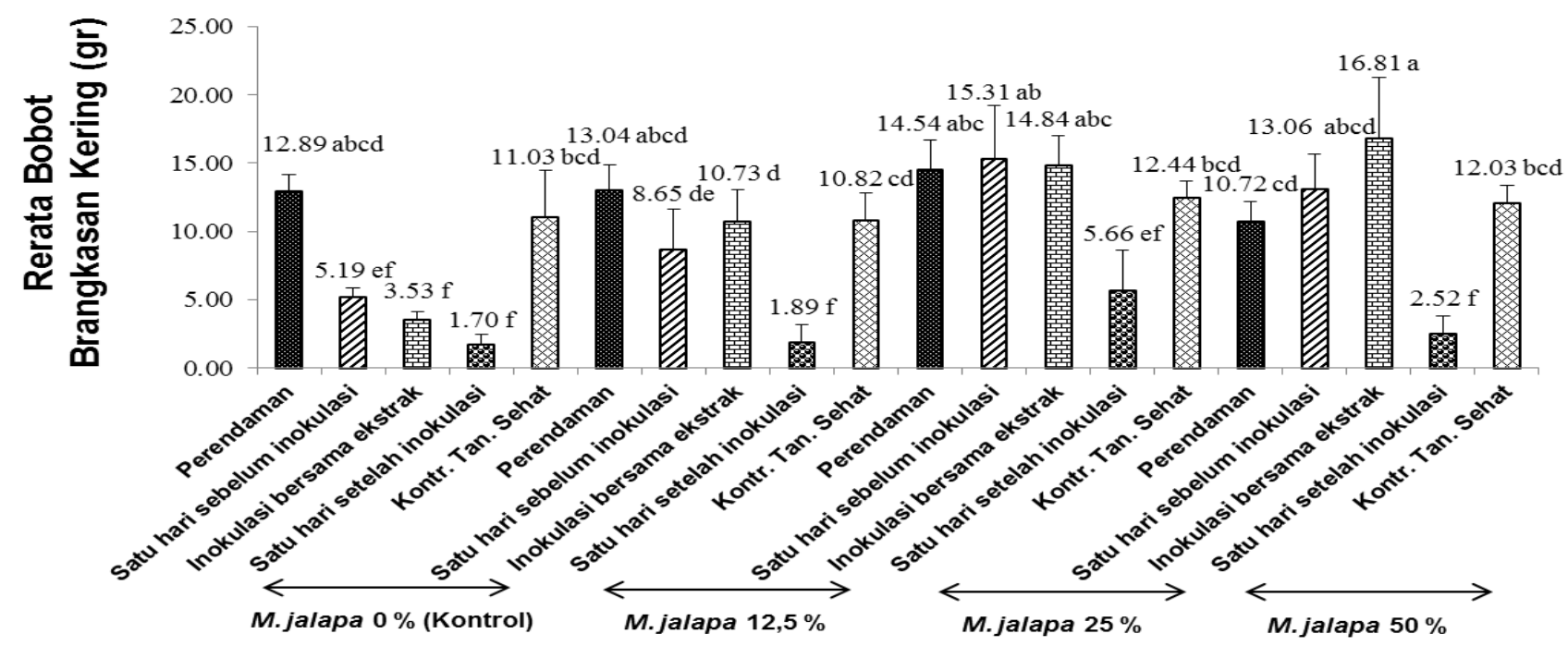

Kombinasi Perlakuan Waktu Aplikasi dan Konsentrasi Ekstrak

Keterangan : Kontr. Tan Sehat $=$ Kontrol tanaman sehat. Antar angka yang diikuti dengan huruf yang sama tidak berbeda nyata pada taraf $5 \%$

Gambar 6 Pengaruh waktu aplikasi dan konsentrasi ekstrak daun M. Jalapa terhadap bobot brangkasan kering kacang panjang 
Pengaruh perlakuan berbagai konsentrasi ekstrak daun M.jalapa menunjukkan bahwa tanaman kontrol sakit memiliki bobot brangkasan kering paling rendah dibanding dengan tanaman yang diaplikasikan ekstrak daun M. jalapa Hal ini sesuai dengan penelitian yang dilakukan oleh Ariyanti (2007) laju asimilasi bersih tanaman sehat lebih tinggi dibandingkan dengan laju asimilasi bersih tanaman terinfeksi virus kuning cabai. Hal ini sangat berpengaruh terhadap hasil produksi tanaman. cabai yang dihasilkan oleh tanaman sehat memilki jumlah dan berat yang lebih tinggi dibandingkan dengan jumlah dan berat buah yang dihasilkan oleh tanaman terinfeksi virus.

Berkurangnya laju fotosintesis menyebabkan penurunan pertumbuhan tanaman. infeksi virus juga menghasilkan biomasa yang rendah, karena adanya penurunan berat kering daun, batang dan akar tanaman mustard (Guoa et al. 2005). Pengaruh perlakuan kombinasi waktu aplikasi dan konsentrasi ekstrak daun M. jalapa terhadap bobot brangkasan kering tanaman menunjukkan hasil bahwa, secara umum tanaman yang diberi perlakuan ekstrak daun $M$. jalapa pada berbagai konsentrasi menunjukkan hasil rerata bobot

\section{KESIMPULAN}

Kesimpulan dari hasil penelitian adalah sebagai berikut:

1. Ekstrak daun bunga pukul empat berperan dalam pengendalian virus, pada hasil uji mampu memperpanjang masa inkubasi, menekan keparahan penyakit, meningkatkat bobot polong

\section{DAFTAR PUSTAKA}

Agrios GN. 2005. Plant pathology. 5th Ed. San Diego (CA): Elsevier Academic Press.

Ariyanti NA. 2007. Mekanisme infeksi virus kuning cabai (Pepper yellow leaf curl virus) dan pengaruhnya terhadap proses fisiologi tanaman cabai. Seminar Nasional VIII Pendidikan Biologi 467-471. Fakultas MIPA, Universitas Negeri Yogyakarta

Boss L. 1990. Pengantar Virologi Tumbuhan. Yogyakarta (ID): Gajah Mada University Press.

Damayanti TA , Hamdayanti. 2014. Infeksi Bean common mosaic virus pada umur tanaman kacang panjang yang berbeda. J Fitopatol Indones. 10 (6) : 181-187.

Damayanti TA, Alabi OJ, Naidu RA et al. 2009. Severe outbreak yellow mosaic disease on the yard long bean in Bogor, West Java. Hayati $\mathrm{J}$ of Biosciences. 16 (2) : 78-72.

Duriat. 2008. Pengaruh Ekstrak Bahan Nabati dalam Menginduksi Ketahanan Tanaman Cabai terhadap Vektor dan Penyakit Kuning Keriting. J Hort. 18(4): 446-456.

Ginting C. 2013. Ilmu Penyakit Tumbuhan. Bandar Lampung (ID): Lembaga Penelitian Universitas Lampung.

Guoa DP, Guoa YP, Zhao, Liua H, Penga Y,Wanga QM, Chenb JS, Raoc GZ. 2005. Photosynthestic rate and chlorophyll fluorescence in leaves of stem brangkasan kering lebih tinggi dibanding dengan tanaman yang tidak diberi perlakuan ekstrak $M$. jalapa (kontrol tanaman sakit). Aplikasi ekstrak M. jalapa pada kombinasi perlakuan antara konsentrasi ekstrak dengan waktu aplikasi menunjukkan hasil yang beragam pada setiap perlakuan. Berdasarkan penelitian, aplikasi ekstrak daun $M$. jalapa terbaik adalah aplikasi ekstrak $50 \%$ bersamaan dengan inokulum, karena menunjukkan hasil bobot brangkasan kering yang tertinggi dibandingkan dengan perlakuan lain. Hal ini terjadi karena kandungan Mirabilis Antiviral Protein (MAP) pada ekstrak daun $M$. jalapa 50\% mampu berkompetisi dengan virus, sehingga dapat mencegah infeksi virus, sesuai dengan Vivanco et al (1999) bahwa mekanisme penghambatan virus yang dilakukan oleh MAP ada dua cara. Yang pertama, pada saat aplikasi ekstrak, MAP masuk ke bagian atas epidermis dan bertahan di ruang antarselnya. Kedua, MAP dan virus melakukan penetrasi bersama-sama pada saat inokulasi. Keduanya saling berkompetisi untuk mencari daerah aktif ribosom sehingga dapat mencegah infeksi virus pada tahap awal sebelum virus mengalami deenkapsidasi.

segar, bobot brangkasan segar maupun bobot brangkasan kering.

2. Ekstrak daun bunga pukul empat 25\% yang diaplikasikan satu hari sebelum aplikasi inokulum merupakan kombinasi ekstrak yang paling efektif untuk mengendalikan virus.

mustard (Brassica juncea var. tsaitsai) after turnip mosaic virus infection. Plant science. 168: 57-63.

Haryanto E, Tina S, Estu R. 2007. Budidaya kacang panjang. Jakarta (ID): Penebar Swadaya

Hersanti. 2004. Pengujian keefektivan ekstrak daun bunga pukul empat (Mirabilis jalapa) dalam menginduksi ketahanan sistemik tanaman cabai merah terhadap serangan Cucumber mosaic virus (CMV)URL:http://repository.unpad.ac.id/5448/1/peng ujian_keefektivan_ekstrak_daun_bunga_pukul_emp at.pdf Diakses pada tanggal 01 April 2015.

Hull R. 2002. Mattews' Plant Virology $4^{\text {th }} E D$. California(LA):Academic Press.

Kementrian Pertanian. 2016. Produksi sayuran Indonesia. http://www.pertanian.go.id. Diakses pada tanggal 01 Maret 2016.

Kurnianingsih L. 2010. Potensi lima ekstrak tumbuhan dalam menekan infeksi mosaik pada tanaman kacang panjang (Vigna unguiculata subsp. Sesquipedalis). Skripsi. Institut Pertanian Bogor. 48 HIm.

Leal N, Lastra R. 1984. Altered metabolism of tomato plants infected with Tomato yellow mosaic virus. Physiological Plant Pathology 24(1) : 1-7.

Madhusudan KN, Vinayarani G, Deepak SA et al. 2011. Antiviral activity of plant extracts and other inducer against Tobamoviruses infection in Bell Pepper and Tomato Plants. Int J Plant Pathol. 2-8. 
Mahar AW. 2012. Deteksi serologi Bean Common Mosaic Virus (BCMV) dari benih kacang panjang (Vigna sinensis L.) komersial dan petani (Abstr). Skripsi. Institut Pertanian Bogor.

Murphy A M, A Gilliand, CE Wong, J West, DP Singh and JP Carr. 2001. Signal transduction in resistance to plant viruses. Euro. J Plant Pathol. 107:121-128.

Nurulita S, Sri HH, Kikin HM, Thomas J. 2015. Molecular characterization of begomovirus invecting yard long bean (Vigna unguiculata subp sesquipedalis L.) in Java, Indonesia. Biotropia 22(1):53-60..

Owen PC. 1957. The effect of infection with Tobacco etch virus on the rates of respiration and photosynthesis of tobacco leaves. Ann. appl. Biol. 45(2).

Owen PC. 1958.Photosyntesis and respiration rates of leaves of Nicotiana glutinosa infected with Tobacco mosaic virus and $N$. tabacum infected with Potato virus X. Ann. App. Biol 46(2) : 198-204.

Setyastuti L. 2008. Tingkat ketahanan sembilan kultivar kacang panjang terhadap Bean common mosaic virus (BCMV). Skripsi. Institut Pertanian Bogor.

Shalitin D, Wolf S. 2000. Cucumber mosaic virus infection affect sugar transport in melon plants. Plant Physiology 123: 597-604.

Srivastava H, Gupta UP, Asha S. 2012. Influence of bean common mosaic virus invection on chlorophyll content and primary productivity in hyacinth bean (Dolichos lablab L.). J Crop Res. 44(1\&2); 174-18

Suryadi D. 2003. Respons ketahanan sepuluh kultivar kacang panjang (Vigna unguiculata subsp. Sesquipedalis) terhadap infeksi virus daun kecil kacang panjang (VDKKP). Skripsi. Institut Pertanian Bogor.

Susetio H. 2011. Penyakit mosaik kuning kacang panjan: respon varietas kacang panjang (Vigna sinensis L.) dan efisiensi penularan melalui kutu daun (Aphis craccivora Koch). Skripsi. Institut Pertanian Bogor.

Susetio H, Hidayat SH. 2014. Respons lima varietas kacang panjang terhadap Bean common mosaic virus. J Patol. 10(4):112-118.

Técsi LI, Smith AM, Maule A J and Leegood RC. 1996. A spatial analysis of physiological changes associated with infection of cotyledons of marrow plants with cucumber mosaic virus. Plant physiol. 111, p.975-985

Vivanco JM, Querci M, Salazar LF. 1999. Antiviral and antiviroid activity of MAP-containing Extracts from Mirabilis jalapa roots. Plant Dis. 83(12): 1116-1121.

Whenham RJ, Fraser RSS, Brown LP, Payne JA. 1986. Tobacco-mosaic-virus induced increase in abscisicacid concentration in tobacco leaves: intracellular location in light and dark-green areas, and relationship to symptom development. Planta 168:592-598. 